\title{
A INFERÊNCIA LEXICAL COMO RECURSO PARA A LEITURA DE GUIMARÃES ROSA
}

\author{
Lexical inference as resource to read Guimarães Rosa
}

Saul Cabral GOMES JR. ${ }^{1}$

Resumo: Este trabalho visa a demonstrar a importância da inferência lexical no processamento do texto de Guimarães Rosa. A fundamentação teórica tem como base as proposições de Kleiman (2004) e de Kato (2000) e, sempre que o material de estudo o exige, faz-se uso da noção de neologismo, analisada por Alves (1994). Comprovase que dois contextos de inferência são fundamentais para a compreensão dos neologismos rosianos: um é o de contraste $e$ comparação; outro é o de conotação. Concluise que, no texto de Guimarães Rosa, a língua alcança o estado metafórico, no qual as possibilidades linguísticas são multiplicadas pela inventividade do falante.

Palavras-chave: Guimarães Rosa. Inferência lexical. Neologismo.

\begin{abstract}
The aim of this work is to show the importance of lexical inference in the processing of Guimarães Rosa's text. The theoretical part of this article is based on Kleiman's (2004)and Kato's (2000) propositions and, whenever the material on focus demands, the notion of neologism as analysed by Alves (1994) is also approached. The research comes to the conclusion that two inferential contexts are fundamental for the understanding of Guimarães Rosa's neologisms: contrast and comparison; connotation. It is the conclusion of this work that, in Guimarães Rosa's text, the language reaches the metaphorical state, in which linguistic possibilities are multiplied by speaker's inventiveness.
\end{abstract}

Keywords: Guimarães Rosa. Lexical inference. Neologism.

1 Gomes Jr. FAFE. Endereço eletrônico: muiraquitan.saul@bol.com.br 
- A inferência lexical como recurso para a leitura de Guimarães Rosa

\title{
A estética modernista e a língua brasileira: a hora e vez de Guimarães Rosa
}

No início do século XX, o movimento modernista desencadeou uma insurreição contra os padrões lusitanos de expressão literária. Impulsionados pela configuração primordial da pesquisa dialetológica no âmbito nacional, os escritores modernistas dedicaram-se à busca da língua brasileira, alheia aos lusitanismos e apta a servir de matériaprima para uma literatura autenticamente nacional.

A postura insurreta dos modernistas se traduziu, inclusive, na adoção de um antiacademismo, em virtude do qual eles abdicaram de uma uniformização de postulados estético-literários. Candido e Castello (1983, p. 9) explicitam:

\begin{abstract}
Os modernistas de 1922 nunca se consideraram componentes de uma escola, nem afirmaram ter postulados rigorosos em comum. O que os unificava era um grande desejo de expressão livre e a tendência para transmitir, sem os embelezamentos tradicionais do academismo, a emoção pessoal e a realidade do País.
\end{abstract}

Nos escritos iniciais de Mário de Andrade, escritor que personificou a iconoclastia na qual se baseou o Modernismo, ostenta-se uma postura linguística antilusitana. Essa postura se evidencia em várias das orientações de Mário ao então poeta-aprendiz Carlos Drummond de Andrade, como se comprova ao se observar o parecer que o autor destinou ao poema drummondiano "Nota social". Nesse parecer, registrado pelo poeta mineiro, substantifica-se a oposição à subserviência estilística dos literatos brasileiros à norma preconizada por cânones lusitanos:

\footnotetext{
Foi uma ignomínia a substituição do na por à estação [no poema "Nota social"] só porque em Portugal paisinho desimportante pra nós diz assim. Repare que eu digo que Portugal diz assim e não escreve só. Em Portugal tem uma gente corajosa que, em vez de ir assuntar como é que dizia na Roma latina e materna, fez uma gramática pelo que se falava em Portugal mesmo. (ANDRADE, M. apud ANDRADE, C. D., 1988, p. 37).
}

Nota-se, no fragmento acima, que o autor reivindica uma efetiva aderência entre a língua falada no Brasil e a língua literária utilizada em âmbito nacional. Na reivindicação de Mário, condensam-se as aspirações linguístico-literárias de uma geração de escritores determinados a estabelecer uma autonomia estilística. Nessa determinação, entrelaçam- 
se propósitos estéticos e parâmetros ideológicos, visto que, nos fundamentos do Modernismo, coexistem a busca de originalidade literária e a contraposição ao purismo² vigente àquela altura. Lessa (1976, p. 30-31) expõe:

[...] com os modernistas, o Português do Brasil intenta atingir uma certa emancipação, sobretudo no que concerne a peculiaridades sintáticas, desassombradamente, corajosamente, com uma coragem e um desassombro com que jamais se houve em épocas passadas. E isto a par de benfazejo combate ao purismo e de uma tentativa de aproximação mais íntima e mais definitiva entre a língua escrita e a língua falada.

O senso libertário do escritor paulistano, ávido por escrever em consonância com a fala e a cultura peculiares do Brasil, inscreve-se em Macunaíma, narrativa referencial para os adeptos da estética modernista:

Então a Sol se queimou e ralhou assim:

- Ara, ara, ara, meus cuidados! Pois não falei pra você não dar em cima de nenhuma cunha não!... [...]

- Pois si você tivesse me obedecido casava com uma das minhas filhas e havia de ser sempre moço e bonitão. [...]

Macunaíma sentiu vontade de chorar. Suspirou.

- Si eu subesse...

(ANDRADE, M., 1993, p. 57)

Nessa obra fundamental de Mário de Andrade, materializa-se a principal aspiração estética dos autores modernistas: "aproximar da realidade brasileira o seu instrumento de expressão literária" (BARBADINHO NETO, 1977, p. 3).

Por assumir uma função paradigmática no Modernismo brasileiro, Mário empenha-se em manter absoluta fidelidade ao projeto estético-literário da Primeira Geração modernista. Esse empenho transparece nitidamente em Macunaíma, narrativa assinalada pelos traços da língua brasileira, presentes tanto nas falas dos personagens quanto na elaboração do narrador. Faria (1982, p. 56) observa:

2 Adota-se, neste trabalho, a concepção de purismo como "prescritivismo", "defesa da norma tradicional". Leite (2006) apresenta um conceito mais amplo de purismo: preconização de um modo de organização linguística, seja ele o padrão linguístico ou qualquer outro. 
- A inferência lexical como recurso para a leitura de Guimarães Rosa

O objetivo de Mário [...] é abolir a dicotomia entre a língua escrita e a falada, uniformizando a sua escritura a partir da contribuição dos modismos da fala corrente. É importante notar que Mário, como autor, faz questão de assumir a responsabilidade dos "erros", isto é, não os coloca apenas na boca de personagens, mas os faz sair também da própria pena.

Com o advento de Macunaíma, consuma-se a insurreição contra a reprodução literária dos moldes linguísticos portugueses. Manifesta-se tal atitude insurreta nos trechos coligidos por Barbadinho Neto (1977, p. 2):

Cassiano Ricardo: "Além da corajosa insubmissão artística, o modernismo se batia por uma linguagem já independente dos lusitanismos sintáticos; mais brasileira no modo de falar e escrever." Rachel de Queiróz: "Quem não vê que, diante da língua falada, cheia de sangue e de força, que vem direta do peito para a boca, como o fôlego, aquela outra língua em que a gente escreve parece uma múmia enfaixada em comparação com um homem vivo? [...] Aí, muito se tem lutado, desde que neste país se escreve, para libertar a fala literária dos seus panos de rotina."

Guimarães Rosa: "Tudo tinha de destruir-se, para dar espaço ao mundo novo aclássico, por perfeito".

Na citação exposta acima, figuram as palavras de João Guimarães Rosa, o mais revolucionário dos escritores modernistas. Impregnada do legado macunaímico, a escritura rosiana comporta uma desconstrução da língua literária, renovada por meio de fecundos procedimentos neológicos. À conceituação de "neologismos" dedica-se Maroneze (2001, p. 16):

Todas as línguas vivas dispõem de mecanismos que possibilitam que seus usuários empreguem a qualquer momento unidades lexicais nunca antes empregadas. Tais unidades recebem o nome de neologismos. Segundo Alves (2004), ao processo de criação lexical dá-se o nome de neologia; o elemento resultante, a nova palavra, é denominado neologismo. Portanto, a neologia é o processo, o neologismo é o seu produto.

A neologia está no cerne do estilo rosiano. Decidido a aprofundar o olhar descritivo que a Primeira Geração modernista dirigira à fala brasileira, Guimarães Rosa adentrou o interior de Minas Gerais, onde encontrou uma língua peculiar. Desse manancial linguístico, Rosa utilizou-se para o seu empreendimento estilístico. 
No sertão mineiro, o ficcionista arraigou a sua obra literária; na oralidade intrínseca a esse ambiente, fundamentou a sua criação linguística. No material coletado pelo pesquisador pertinaz, imprime-se a criatividade do escritor notável. A partir desse material linguístico, Rosa constrói uma outra língua literária, na qual os neologismos são elementos essenciais. Martins (1994, p. 87) destaca:

Os neologismos, que constituem um traço estilístico marcante na obra de Guimarães Rosa, não se originam da necessidade de designação de coisas novas, não refletem a vida moderna e seus progressos. [...] Eles resultam da busca de expressividade, de originalidade e de pitoresco. São afirmações da liberdade de expressão do artista, que não se satisfaz com o léxico dicionarizado.

A avidez estilística de Guimarães Rosa o torna um cultivador dos campos neológicos, um escultor de palavras novas. Os procedimentos neológicos seriam, no dizer do próprio ficcionista, um modo de apresentar "novas maneiras de sentir e de pensar" ao leitor:

\begin{abstract}
Não procuro uma linguagem transparente. Ao contrário, o leitor tem de ser chocado, despertado de sua inércia mental, da preguiça e dos hábitos. Tem de tomar consciência viva do escrito, a todo momento. Tem quase de aprender novas maneiras de sentir e de pensar. (ROSA, 1959 apud MARTINS, 2001, p. 1). ${ }^{3}$
\end{abstract}

A escritura rosiana encontra-se imbuída de inovações lexicais. Para que se depreendam os significados dessas palavras não dicionarizadas, faz-se necessário que o indivíduo adote procedimentos específicos de leitura. Neste estudo, optou-se por abordar o procedimento mais proveitoso para a decifração do código rosiano: a inferência lexical.

Antes de se demonstrar a importância desse procedimento para a compreensão do texto de Guimarães Rosa, propósito em que se concentra este trabalho, faz-se conveniente uma breve exposição de aspectos da neologia rosiana. A essa apresentação destina-se o tópico seguinte.

3 Carta de Guimarães Rosa a Harriet de Onis, citada no preâmbulo da obra de Martins (2001). 
- A inferência lexical como recurso para a leitura de Guimarães Rosa

\title{
A escrita rosiana: reconstrução da palavra e construção de um estilo
}

Para constituir a sua insígnia estilística, Guimarães Rosa procedeu a uma desconstrução da língua literária nacional, retirando-lhe a configuração tradicional, por meio da qual os leitores brasileiros estavam habituados a depreender os textos ficcionais.

O ficcionista desconstrói a língua literária na medida em que desarticula formas linguísticas tradicionais para estabelecer palavras novas, nas quais baseia a sua peculiar tessitura narrativa. Ao estabelecê-las, Rosa transgride a estruturação convencional do português. Assim, na escritura rosiana, institui-se uma outra norma, um outro modo de organização linguística. A posição intermediária da norma, que se situa entre o conjunto de possibilidades de que dispõe o falante e o ato linguístico consumado, é explicitada por Coseriu (1987, p. 72):

\begin{abstract}
Num primeiro grau de formalização, [as] estruturas [linguísticas] são simplesmente normais e tradicionais na comunidade, constituem o que chamamos norma; mas, num plano de abstração mais alto, depreende-se delas mesmas uma série de elementos essenciais e indispensáveis de oposições funcionais: o que chamamos sistema. [...] Vale dizer que o sistema e a norma não são realidades autônomas e opostas ao falar e tampouco "aspectos do falar", que é uma realidade unitária e homogênea, mas [...] abstrações que são elaboradas sobre a base da atividade linguística concreta, em relação com os modelos que utiliza.
\end{abstract}

O aspecto transgressor da escrita rosiana se evidencia, por exemplo, no conto "Substância", no qual se encontram os vocábulos coraçãomente e pensamor, incluídos no estudo lexicográfico de Martins (2001):

CORAÇÃOMENTE. [...] Com todo o coração, em estreita fusão de sentimento. // O adv. cordialmente, já gasto, até burocratizado, não podia satisfazer ao tom lírico desejado pelo Autor. Criou então essa forma insólita em que o substantivo-radical é preservado na sua inteireza. (p. 134)

PENSAMOR. [...] Amálgama de pensamento e amor, sugerindo a inseparabilidade de pensar e amar. (p. 379)

Ao integrar o sufixo -mente a um substantivo (contrariando a tradição de que esse sufixo, para constituir advérbios de modo, une-se a adjetivos) e aglutinar os vocábulos pensamento e amor em uma só palavra, Rosa estabelece uma outra seleção dos elementos 
oferecidos pelo sistema, ou seja, instaura uma outra norma, que passa a coexistir com a norma convencional do português.

As transgressões rosianas originam-se do objetivo tenaz de renovar a língua, para alcançar o máximo de expressividade literária. Guimarães Rosa sublima o empreendimento criativo que assinala o ofício do escritor. Todo literato, por fundamentar o seu trabalho na busca da expressão adequada, exerce constantemente a criatividade linguística. Nesse exercício, arraigam-se os desvios da língua comum, aos quais Monteiro (1991, p. 15) atribui a denominação de "desvios expressivos":

\begin{abstract}
$\mathrm{Na}$ realidade, quando se fala em desvio expressivo, pretende-se realçar o aspecto de criatividade exercido sobre a linguagem. [...]

Diz-nos Murry (1949) que o escritor está perpetuamente procurando forçar a linguagem a carregar mais do que pode conduzir, incessantemente exercendo uma espécie de delicada violência sobre a linguagem. O motivo real para assim proceder é o seu impulso, o seu desejo de encontrar uma forma precisa para o seu conteúdo.
\end{abstract}

Rosa converteu tais desvios na essência do seu estilo. O ficcionista elevou a criatividade literária a um nível extraordinário, a tal ponto que não apenas estabelece desvios da norma, mas institui uma outra norma.

As reconstruções linguísticas de Guimarães Rosa consistem em transgressões da norma, no entanto, enquadram-se na macrounidade denominada por Coseriu de "sistema". Nessa macrorrealidade linguística, encontram-se os recursos dos quais se utiliza o leitor para depreender os significados dos vocábulos rosianos. Ao se utilizar de tais recursos, o indivíduo ativa seu conhecimento linguístico, a partir do qual se empreende a inferência lexical, como se demonstrará a seguir.

\title{
As veredas da inferência nos despercursos do léxico
}

\section{O horizonte do léxico e o olhar inferencial}

Pode-se afirmar que, no léxico, está a carga significativa da língua; é nesse conjunto de palavras que se concentra o conteúdo linguístico, a partir do qual o falante expressa as suas ideias e apreende a mensagem do interlocutor. No léxico, baseia-se a interação social, porque nele estão os significados que possibilitam a compreensão mútua entre os 
- A inferência lexical como recurso para a leitura de Guimarães Rosa

indivíduos. Biderman (1981, p. 132) identifica no léxico o patrimônio social da comunidade linguística:

\begin{abstract}
Se considerarmos a dimensão social da língua, podemos ver no léxico o patrimônio social da comunidade por excelência, juntamente com outros símbolos da herança cultural. Dentro desse ângulo de visão, esse tesouro léxico é transmitido de geração a geração como signos operacionais, por meio dos quais os indivíduos de cada geração podem pensar e exprimir seus sentimentos e ideias.
\end{abstract}

Como transparece na citação exposta acima, há vínculos sólidos entre a língua e a cultura, os quais se inscrevem no léxico, componente linguístico por meio do qual os elementos culturais são expressos. Ao definir cultura, Câmara Jr. (1997, p. 87-88) explicita que, no léxico, se imprimem as mudanças linguísticas:

CULTURA - Conjunto das criações do homem que constituem um universo humano, ou SUPERORGÂNICO, acima do universo físico, ou inorgânico, e do universo biológico, ou orgânico. As línguas são produtos da cultura para permitir a comunicação social. As mudanças na cultura determinam mudanças linguísticas, principalmente no que se refere $[. .$.$] ao léxico [...].$

Por ser uma construção social, a cultura possui um caráter essencialmente dinâmico. O dinamismo cultural, responsável pela renovação contínua das formas de ação em sociedade, manifesta-se por intermédio da língua, fazendo-se perceptível principalmente no léxico. É por meio do léxico que se depreende, primordialmente, a língua; é pela via lexical que se apresentam, primeiramente, os traços da mutabilidade linguístico-cultural.

Devido a essa função primordial na depreensão da língua, o léxico exerce um papel fundamental na leitura. A compreensão de um texto se arraiga no plano léxico-semântico, ou seja, no âmbito das palavras e de seus significados. A investigação dos campos léxicosemânticos de uma produção textual, conforme expõe Losano (2015), permite analisar como o indivíduo organiza seu pensamento diante do vocabulário de um texto e como a estrutura deste campo como um todo poderá ajudar na interpretação desse texto.

O conhecimento dos elementos léxico-semânticos é um componente do conhecimento linguístico, a partir do qual se estabelece, primariamente, a interação texto X leitor. Atente-se à explanação de Kleiman (2000, p. 13): 
São vários os níveis de conhecimento que entram em jogo durante a leitura. [Destaque-se] o conhecimento linguístico, isto é, aquele conhecimento implícito, não verbalizado [...]. Este conhecimento abrange desde o conhecimento sobre como pronunciar português, passando pelo conhecimento de vocabulário e regras da língua, chegando até o conhecimento sobre o uso da língua.

A depreensão dos vocábulos, possibilitada pelo conhecimento linguístico, é essencial para que o texto seja processado pelo leitor, para que os sentidos textuais sejam construídos. O processamento do texto permite que o indivíduo perceba a macrounidade textual, constituída de unidades menores, como a frase e a palavra. Kleiman (2000, p. 1415) assinala:

O conhecimento linguístico desempenha um papel central no processamento do texto. Entende-se por processamento aquela atividade pela qual as palavras, unidades discretas, distintas, são agrupadas em unidades ou fatias maiores, também significativas, chamadas constituintes da frase. À medida que as palavras são percebidas, a nossa mente está ativa, ocupada em construir significados [...].

Para que se instaure a depreensão do léxico - e, consequentemente, ocorra o processamento do texto -, duas estratégias de leitura se fazem fundamentais: a ascendente e a descendente. A elas volta-se o olhar analítico de Kato (2000, p. 68):

[...] a abordagem sintática é mais linear, enquanto que a semântica opera com idas e vindas. A esse tipo de abordagem mais linear e mais indutiva convencionou-se chamar de estratégia ascendente (bottom-up), e à abordagem que usa processos dedutivos a partir de expectativas do leitor, de estratégia descendente (top-down).

Mostram-se, desse modo, diferenças nítidas entre as duas estratégias: a estratégia ascendente relaciona-se a uma leitura linear, baseada na apreensão de elementos formais, presentes explicitamente no texto; a estratégia descendente vincula-se a outras habilidades apresentadas pelo leitor, a partir das quais o indivíduo estabelece deduções, utilizandose de indícios semânticos para reconstruir o texto.

A estratégia descendente contribui substancialmente para o processamento de um texto no qual há vocábulos que o leitor desconhece. Ao empregá-la, o indivíduo adquire a percepção das pistas linguísticas no texto, as quais lhe permitem deduzir o significado da palavra desconhecida. Kato (2000, p. 76) assevera: 
- A inferência lexical como recurso para a leitura de Guimarães Rosa

Acredita-se que um texto com muitas palavras desconhecidas seja de leitura difícil e se processe palavra por palavra. Na verdade, o que influi na escolha do processo é a possibilidade ou não de o texto oferecer condições para o leitor inferir seu significado. A existência de palavras desconhecidas fará com que ele use muito de sua capacidade de processamento descendente, pois o ascendente não o faz progredir em sua compreensão.

Na noção de pistas linguísticas - os indícios textuais que nos permitem verificar aspectos da intencionalidade do autor e identificar significados implícitos no texto -, encontra-se arraigado outro conceito, bastante proveitoso para os estudos acerca da leitura. Trata-se da inferência lexical, procedimento sobre o qual disserta Kleiman (2004, p. 73):

O conceito de INFERÊNCIA LEXICAL depende de outros conceitos, como contexto, ou pistas linguísticas, para ser compreendido. Eles são necessários para explicar [...] o processo pelo qual aprendemos as palavras paulatinamente, mediante a análise e incorporação dos contextos em que elas se inserem [...].

Como se evidencia na citação exposta acima, a inferência lexical é o procedimento pelo qual o leitor deduz o significado de um vocábulo desconhecido a partir de um certo contexto. Quando o significado exato desse vocábulo não é uma condição para que o indivíduo prossiga a leitura, tal procedimento é profícuo, demonstrando que, em determinadas circunstâncias, as habilidades do leitor tornam dispensável o uso do dicionário. Observe-se a elucidação de Kleiman (2004, p. 69):

Quando a compreensão do texto não depende de conhecer a definição exata da palavra, outras abordagens, que imitam a maneira natural de aprender palavras, são mais adequadas para a aprendizagem de vocabulário. [...] Quando nos deparamos com uma palavra pela primeira vez [...], adquirimos uma ideia aproximada do significado da expressão, a partir do contexto linguístico em que ela é usada.

Por se concentrar na noção de contexto linguístico, a inferência lexical revela-se um conceito produtivo para os estudos pragmáticos do texto. Ao analisar as contribuições da perspectiva pragmática para a constituição de uma Linguística do texto, Fiorin (1995, p. 93) explicita os vínculos entre o ângulo pragmático e a focalização do contexto: 
[...] a pragmática cria um novo objeto teórico, o uso da linguagem, e, por isso, procura reconhecer e analisar uma série de variáveis extralinguísticas que sobredeterminam, nas diferentes condições de emprego e nos diversos contextos de uso, as formas e construções linguísticas efetivamente utilizadas pelo enunciador. [...] Uma Linguística do discurso ou do texto não pode ignorar o contexto em que o objeto se insere.

$\mathrm{Na}$ focalização do contexto assenta a inferência lexical, procedimento essencial para a ampliação dos conhecimentos léxico-semânticos. Esses conhecimentos são fundamentais para a depreensão do texto rosiano, composto basicamente por palavras reconstruídas, cujos sentidos emergem quando o leitor adota o procedimento citado.

\section{As potencialidades do leitor e as minas rosianas}

A neologia caracteriza, fundamentalmente, o estilo de Guimarães Rosa. Para depreender os significados dos neologismos rosianos, o leitor pode recorrer, especificamente, a dois dos vários contextos de inferência arrolados por Kleiman (2004): ao de contraste e comparação e ao de conotação.

A fim de demonstrar a sólida contribuição dessa recorrência para a compreensão do texto rosiano, neste estudo, adotam-se como corpus as seguintes narrativas do ficcionista mineiro: Grande sertão: veredas (GSV); A hora e vez de Augusto Matraga (HVAM); e os contos "Substância" e "A terceira margem do rio", que entram na composição de Primeiras estórias (PE).

Na categorização estabelecida por Alves (1994) baseia-se a terminologia utilizada para classificar os neologismos analisados, agrupados de acordo com o contexto de inferência ao qual se vinculam.

\section{1. Contraste e comparação}

Nesse contexto, instauram-se "relações de comparação ou de contraste entre um item desconhecido e algum outro no texto" (KLEIMAN, 2004, p. 77). Nele, a inferência lexical ocorre por meio do confronto do vocábulo desconhecido com um outro que a ele se relacione estruturalmente e que o leitor conheça. A partir desse cotejo, o significado da palavra desconhecida se faz dedutível. 
- A inferência lexical como recurso para a leitura de Guimarães Rosa

Ao contexto de contraste e comparação vinculam-se os neologismos sintáticos, cuja apreensão exige a ativação de conhecimentos linguísticos prévios, como ressalta Turazza (1996, p. 255):

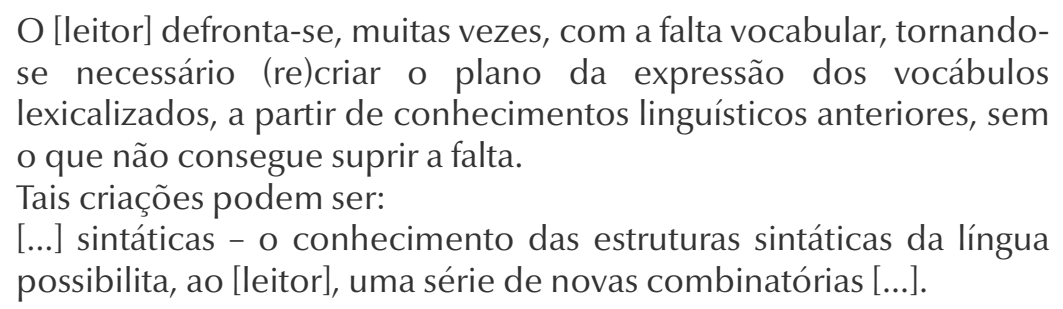

Ao empregar o seu conhecimento das estruturas sintáticas, o leitor verifica na palavra desconhecida uma negação ou uma transmutação da palavra conhecida. Tais verificações são possíveis nos fragmentos rosianos expostos a seguir.

a. Derivação prefixal

(1) Pareceu até que, de algum encoberto jeito, eu daquilo já sabia. Assim já tinha ouvido de outros, aos pedacinhos, ditos e indiretas, que eu desouvia. Perguntar a ele, fosse? Ah, eu não podia, não. Perguntar a mais pessoa nenhuma; chegava. (GSV, p. 95-96, grifo nosso)

(2) Sionésio e Maria Exita - a meios-olhos, perante o refulgir, o todo branco. Acontecia o não-fato, o não-tempo, silêncio em sua imaginação. ( $P E$, p. 142, grifo nosso)

Em relação ao exemplo 1, o confronto da palavra desouvia com a palavra conhecida ouvia possibilita que se infira o significado do neologismo grifado: "deixava de ouvir". Nesse caso, a inferência lexical é favorecida pela alta produtividade do prefixo des- na língua portuguesa, o qual expressa, basicamente, "o valor de 'separação' da base a que se associa" (ALVES, 1994, p. 16).

Na escritura rosiana, destina-se a esse prefixo um espaço considerável, visivelmente superior àquele reservado ao prefixo in-. Alves (2011, p. 211) afirma:

\footnotetext{
Muitos dos neologismos rosianos criados com o prefixo $D E S$ - resultam de uma permuta com o prefixo $I N-$, o que não deixa de ser singular. $I N-$, prefixo muito pouco empregado por Guimarães Rosa, é muitas vezes substituído por DES-, que Daniel (1968) assim apresenta: o prefixo negativo de maior frequência na obra rosiana é $D E S-$-, o qual ocorre umas quarenta vezes.
} 
No que se refere ao exemplo 2, retirado do conto "Substância", o cotejo dos vocábulos destacados com as palavras "fato" e "tempo" permite depreendê-los como vocábulos que se constituem antíteses dessas palavras.

A junção do advérbio não a outros vocábulos corrobora o propósito de "negarIhes totalmente o significado" (ALVES, 1994, p. 15).

b. Derivação sufixal

(3) Medeiro Vaz não era carrancista. Somente de mais sisudez, a praxe, homem baseado. Às vezes, vinha falando surdo, de resmão. Com ele, ninguém vereava. De estado calado, ele sempre aceitava todo bom e justo conselho. Mas não louvava cantoria. (GSV, p. 36, grifo nosso)

(4) Eu dizendo que a Mulher ia lavar o corpo dele. Ela rezava rezas da Bahia. Mandou todo o mundo sair. Eu fiquei. E a Mulher abanou brandamente a cabeça, consoante deu um suspiro simples. Ela me mal-entendia. Não me mostrou de propósito o corpo. (GSV, p. 453, grifo nosso)

(5) Assim; mas era também o exato, grande, o repentino amor - o acima. Sionésio olhou mais, sem fechar o rosto, aplicou o coração, abriu bem os olhos. Sorriu para trás. [...] o viver em ponto sem parar, coraçãomente [...]. ( $P E$, p. 142, grifo nosso)

No exemplo 3, destacou-se o vocábulo carrancista, qualificação definida por Martins (2001, p. 104) do seguinte modo: "Carrança, pessoa apegada ao passado; que não esquece coisas antigas". Na definição estabelecida pela autora, ratifica-se o papel fundamental do sufixo-ismo, que "se une a bases substantivas, adjetivas e, mais raramente, distribui-se entre bases verbais e sintagmáticas, denotadoras de 'personalidades, de ideias e de siglas partidárias'" (ALVES, 1994, p. 29). Dessa forma, infere-se que carrancista é aquele que preconiza o carrancismo, isto é, que pratica e difunde o apego a coisas passadas.

No exemplo 4, o neologismo grifado origina-se da integração de uma desinência verbal ao substantivo "mal-entendido". No fragmento analisado, deduz-se que malentender significa "compreender mal", "submeter a um mal-entendido".

No vocábulo destacado no exemplo 5, extraído do conto "Substância", observa-se a junção do sufixo -mente ao substantivo "coração", por meio da qual se anula a principal característica desse sufixo, intensamente produtivo ao "juntar-se a bases adjetivas femininas para designar 'modo'"' (ALVES, 1994, p. 35). 
O neologismo coraçãomente, já mencionado neste trabalho como integrante do estudo lexicográfico de Martins (2001), provém da força simbólica do vocábulo "coração", que, na escrita rosiana, mantém uma relação de sinonímia com a palavra "amor". Ao se perceber essa relação, infere-se que coraçãomente significa "ao modo do coração", "de modo amoroso".

c. Composição coordenativa

(6) Também, não fumava mais, não bebia, não olhava para o bomparecer das mulheres, não falava junto em discussão. Só o que ele não podia era se lembrar da sua vergonha; mas ali, naquela biboca perdida, fim-de-mundo, cada dia que descia ajudava a esquecer [...]. (HVAM, p. 25-26, grifo nosso)

No exemplo 6, verifica-se um neologismo configurado a partir de um processo de composição, no qual um adjetivo e um verbo "associam-se copulativamente a fim de formarem esse neologismo" (ALVES, 1994, p. 45). Em tal associação, o verbo substantivado "parecer" recebe a qualificação "bom", resultando no substantivo bom-parecer, cujo significado inferido é "boa aparência".

\section{2. Conotação}

Nesse contexto, compõe-se um agrupamento semântico dentro do qual o significado do vocábulo desconhecido se torna dedutível a partir das sugestões estabelecidas pela teia semântica na qual esse vocábulo se encontra. A conotação instaura um processo gradativo, no qual a palavra desconhecida é antecedida (e, às vezes, seguida) por uma sequência de elementos textuais que colaboram para a depreensão do seu significado. Kleiman (2004, p. 78) expõe:

Também através dos efeitos e associações que as palavras sugerem, por pertencerem a um mesmo campo semântico, por exemplo, torna-se às vezes possível adivinhar o significado aproximado de uma palavra desconhecida, desde que ela seja do mesmo campo.

Ao contexto de conotação relacionam-se os neologismos semânticos, singularizados por se fundamentarem numa nova significação para uma forma inalterada. A neologia semântica não provém da transmutação fonológica, mas da atribuição de uma nova substância significativa a um vocábulo existente. A essa neologia dirigem-se as seguintes observações de Barbosa (1996, p. 202): 
A neologia semântica distingue-se das outras formas de neologia pelo fato de que a substância significante utilizada como base préexiste no léxico, enquanto morfema lexical. [...] a neologia semântica pode ser definida como o surgimento de uma significação nova para um mesmo segmento fonológico.

$\mathrm{Na}$ escritura rosiana, o neologismo semântico transcende o aspecto formal de vocábulo, para assumir o aspecto de construção vocabular, na qual um verbo se entrelaça com outro vocábulo, na mesma contextura sintagmática, para constituir uma unidade léxico-semântica. Percebe-se a neologia semântica em "A terceira margem do rio", conto do qual se extraiu o fragmento abaixo:

(7) Era a sério. [...] Nosso pai nada não dizia. Nossa casa, no tempo, ainda era mais próxima do rio, obra de nem quarto de légua: o rio por aí se estendendo grande, fundo [...]. E esquecer não posso, do dia em que a canoa ficou pronta. [...] Sem alegria nem cuidado, nosso pai encalcou o chapéu e decidiu um adeus para a gente. (PE, p. 32, grifo nosso)

No exemplo 7, o significado da construção decidiu um adeus pode ser depreendido da sequência de descrições que a antecedem (a seriedade e o silêncio do pai; a construção da canoa), por meio das quais se instaura um clima de despedida, que culmina com o gesto do pai do narrador. Associando tal sequência ao neologismo grifado, infere-se que decidiu um adeus significa "deu um adeus de forma decisiva".

Também se verifica um neologismo semântico em Grande sertão: veredas, especificamente na passagem em que Riobaldo se depara com o corpo feminino de Diadorim, que assumira a identidade de um jagunço:

(8) Eu estendi as mãos para tocar naquele corpo, e estremeci, retirando as mãos para trás [...]: abaixei meus olhos. E a Mulher estendeu a toalha, recobrindo as partes. Mas aqueles olhos eu beijei, e as faces, a boca. Adivinhava os cabelos. Cabelos que cortou com tesoura de prata... Cabelos que, no só ser, haviam de dar para baixo da cintura... (GSV, p. 454, grifo nosso)

No exemplo 8, o significado da construção adivinhava os cabelos emana da tessitura poético-descritiva em meio à qual a feminidade de Diadorim, que morrera num confronto de jagunços, é revelada a Riobaldo.

Após a revelação de que o jagunço morto é uma mulher, o protagonista vê-se livre para expressar o seu amor e procura reconstituir em sua imaginação os traços femininos 
- | A inferência lexical como recurso para a leitura de Guimarães Rosa

de Diadorim, atitudes que ficam explícitas no fragmento em análise. Na reconstituição empreendida por Riobaldo, incluem-se os cabelos da mulher Diadorim. A partir dessa inclusão, deduz-se que adivinhava os cabelos significa "presumia como eram os cabelos antes do corte com tesoura de prata".

\section{À terceira margem de uma conclusão}

Os neologismos rosianos revelam, além da plena absorção da herança macunaímica, uma engenhosidade estilística que se fez única na literatura em língua portuguesa.

Guimarães Rosa conjugou o legado estético da Primeira Geração modernista com a propensão dialetológica que germinou paralelamente ao Modernismo brasileiro, tornando-se um autêntico literato-linguista. Ao se voltar para a riqueza dialetal intrínseca ao sertão de Minas Gerais, o ficcionista encontrou a matéria-prima para exercer a sua extraordinária criatividade. Desse exercício, provêm as inovações que singularizam a escritura rosiana, por meio das quais se inserem as formas linguísticas no plano metafórico. A metáfora é um artifício capaz de alargar consideravelmente o vocabulário, como ressalta Ricouer (1983, p. 283):

\footnotetext{
A metáfora [...] é, antes de mais, capaz de alargar o vocabulário, quer fornecendo uma orientação para a denominação de novos objectos, quer oferecendo para os termos abstractos similitudes correctas (assim, a palavra cosmos, depois de ter significado a disposição dos cabelos ou os arreios de um cavalo, veio a designar a ordem de um exército, e depois a ordem do universo).
}

No texto rosiano, a língua é alçada permanentemente ao estado metafórico, no qual as possibilidades linguísticas são multiplicadas pela inventividade do falante. Ao exercitar literariamente esse potencial inventivo, Rosa sublimou o jogo linguístico, incluso no rol das funções da literatura por Tavares (1991), que prefere chamá-lo de "exercício lúdico". Das alquimias rosianas emerge um léxico reinventado, pronto a ser inferido, destinado a desafiar a inteligência do sujeito-leitor. 


\section{Referências}

ALVES, I. M. Neologismo: criação lexical. 2. ed. São Paulo: Ática, 1994.

A neologia em Guimarães Rosa: subsídios para o estudo da estilística lexical. In: HENRIQUES, C. C. (Org.). Estilística e discurso: estudos produtivos sobre texto e expressividade. Rio de Janeiro: Elsevier, 2011.

ANDRADE, C. D. A lição do amigo: cartas de Mário de Andrade a Carlos Drummond de Andrade. 2. ed. Rio de Janeiro: Record, 1988.

ANDRADE, M. Macunaíma: o herói sem nenhum caráter. 29. ed. Belo Horizonte: Villa Rica, 1993.

BARBADINHO NETO, R. Sobre a norma literária do modernismo. Rio de Janeiro: Ao Livro Técnico, 1977.

BARBOSA, M. A. Léxico, produção e criatividade: processos do neologismo. 3. ed. São Paulo: Plêiade, 1996.

BIDERMAN, M. T. C. A estrutura mental do léxico. In: Estudos de filologia e linguística: em homenagem a Isaac Nicolau Salum. São Paulo: T. A. Queiroz / EDUSP, 1981.

CÂMARA JR., J. M. Dicionário de linguística e gramática. 18. ed. Petrópolis: Vozes, 1997.

CANDIDO, A.; CASTELLO, J. A. Presença da literatura brasileira: modernismo. 9. ed. São Paulo: DIFEL, 1983.

COSERIU, E. Sistema, norma e fala. In: Teoria da linguagem e linguística geral. Tradução de A. D. Carneiro. 2. ed. Rio de Janeiro: Presença, 1987.

FARIA, J. R. G. Mário de Andrade e a questão da língua brasileira. In: Estudos sobre o modernismo. Curitiba: Criar, 1982.

FIORIN, J. L. Contexto e compreensão. In: CONGRESSO BRASILEIRO DE LINGUÍSTICA APLICADA, 4., 1995, Campinas. Anais... Campinas: UNICAMP, 1995. p. 93-97. 
- | A inferência lexical como recurso para a leitura de Guimarães Rosa

KATO, M. No mundo da escrita: uma perspectiva psicolinguística. 7. ed. São Paulo: Ática, 2000.

KLEIMAN, A. Texto e leitor: aspectos cognitivos da leitura. 7. ed. Campinas: Pontes, 2000.

Oficina de leitura: teoria e prática. 10. ed. Campinas: Pontes, 2004.

LEITE, M. Q. Metalinguagem e discurso: a configuração do purismo brasileiro. 2. ed. São Paulo: Humanitas, 2006.

LESSA, L. C. O modernismo brasileiro e a língua portuguesa. 2. ed. Rio de Janeiro: Grifo, 1976.

LOSANO, T. Estratégias de leitura no ensino de língua portuguesa: a observação das escolhas lexicais e seu efeito de sentido nos contos de Lygia Fagundes Telles. 2015. $113 \mathrm{f}$. Dissertação (Mestrado em Filologia e Língua Portuguesa) - Faculdade de Filosofia, Letras e Ciências Humanas, Universidade de São Paulo, São Paulo, 2015.

MARONEZE, B. O. Um estudo da mudança de classe gramatical em unidades lexicais neológicas. 2011. 199 f. Tese (Doutorado em Filologia e Língua Portuguesa) - Faculdade de Filosofia, Letras e Ciências Humanas, Universidade de São Paulo, São Paulo, 2011.

MARTINS, N. S. João Guimarães Rosa. In: PINTO, E. P. (Org.). O escritor enfrenta a língua. São Paulo: FFLCH/USP, 1994.

O léxico de Guimarães Rosa. São Paulo: EDUSP, 2001.

MONTEIRO, J. L. A estilística. São Paulo: Ática, 1991.

RICOEUR, P. O trabalho da semelhança. In: A metáfora viva. Tradução de Joaquim Torres Costa e Antonio Magalhães. Porto: Rés, 1983.

ROSA, J. G. Grande sertão: Veredas. 13. ed. Rio de Janeiro: José Olympio, 1979. Primeiras estórias. 14. ed. Rio de Janeiro: Nova Fronteira, 1985.

. A hora e vez de Augusto Matraga. Rio de Janeiro: Nova Fronteira, 1996. 
TAVARES, H. Teoria literária. 10. ed. Belo Horizonte: Villa Rica, 1991.

TURAZZA, J. S. Léxico e criatividade. São Paulo: Plêiade, 1996.

COMO CITAR ESTE ARTIGO: GOMES JR., Saul Cabral. A inferência lexical como recurso para a leitura de Guimarães Rosa. Revista do GEL, v. 15, n. 1, p. 130-148, 2018. Disponível em: https://revistadogel.gel.org.br/.

DOI: http://dx.doi.org/10.21165/gel.v15i1.1839

Submetido em: 28/05/2017. | Aceito em: 27/02/2018. 